\title{
Qualitative and Quantitative Determination of Phytochemical Contents of Indigenous Nigerian Softwoods
}

\author{
Chukwuma S. Ezeonu' ${ }^{1}$ and Chigozie M. Ejikeme ${ }^{2}$ \\ ${ }^{1}$ Department of Biochemistry, Federal University Wukari, Taraba State, Nigeria \\ ${ }^{2}$ Department of Chemical Sciences, Godfrey Okoye University, Thinkers Corner, Enugu, Nigeria \\ Correspondence should be addressed to Chukwuma S. Ezeonu; chuksmaristos@yahoo.com
}

Received 26 April 2016; Revised 16 August 2016; Accepted 18 September 2016

Academic Editor: Hamid Reza Sadeghnia

Copyright ( 2016 C. S. Ezeonu and C. M. Ejikeme. This is an open access article distributed under the Creative Commons Attribution License, which permits unrestricted use, distribution, and reproduction in any medium, provided the original work is properly cited.

\begin{abstract}
The phytochemical contents of some milled Nigerian softwood chips were carried out in a quest to evaluate their potentials as sources of alternative medicine as well as uses in other industrial applications. The qualitative and quantitative analysis were ascertained. Tannin was found in all the Nigerian softwoods examined with the highest quantities obtained in Sterculia oblonga $(1240 \mathrm{mg} / 100 \mathrm{~g})$ and Barteria nigritiana $(1230 \mathrm{mg} / 100 \mathrm{~g})$. Highest quantities of alkaloid were obtained in Cordia millenii (11.2\%) and Sterculia oblonga (10.4\%). Barteria nigritiana (14.2\%) and Moringa oleifera (12.2\%) recorded more flavonoid content than other individual softwoods. Saponin was more in Anogeissus leiocarpus (12.5\%) and Dichrostachys cinerea (9.8\%). Oxalate was found to be higher in Combretodendron macrocarpum $(5.84 \mathrm{~g} / 100 \mathrm{~g})$ and Glyphaea brevis $(3.55 \mathrm{~g} / 100 \mathrm{~g})$. Pentaclethra macrophylla $(890 \mathrm{mg} / 100 \mathrm{~g})$ and Moringa oleifera $(880 \mathrm{mg} / 100 \mathrm{~g})$ contained more cyanogenic glycosides. Sacoglottis gabonensis $(4.68 \mathrm{mg} / \mathrm{g})$ and Pentaclethra macrophylla (4.04 mg/g) showed the highest contents of phenol, while more lipids ( $8 \%$ and $7.2 \%$ ) were found in Anogeissus leiocarpus and Kaempferia galanga, respectively. The results showed that these Nigerian softwoods grains could be a source for the exploitation of these phytochemicals beneficial in the pharmaceutical and alternative medicine industries.
\end{abstract}

\section{Introduction}

Nigeria abounds in diverse forest and natural resources. Forest trees are found in various parts of the country where they are lumbered and sold locally for house building and various construction purposes. Phytochemical studies of softwood stem $v i s-\grave{a}$-vis Nigerian timber components have been inadequate as the focuses of most research are on leaves and fruits of these plants. Some of these softwood stems contain phytochemicals locally extracted using alcohol or in aqueous form by traditional drug peddlers, showing that they have undocumented medicinal values. The medicinal value of plant lies in the phytochemical (bioactive) constituents of the plant which shows various physiological effects on human body. Therefore, through phytochemical screening one could detect the various important compounds which may be used as the bases of modern drugs for curing various diseases [1]. Chemical compounds produced as a result of metabolic reaction during plant growth are known as phytochemicals. Harborne [2] and Okwu [3] refer to such metabolic chemicals as "secondary metabolites" which include alkaloids, flavonoids, coumarins, tannins, terpenes, terpenoids, phenols, gums, polysaccharides, and glycosides. Human bodies under stress condition produce less enzymatic antioxidants (e.g., superoxide dismutase (SOD), glutathione peroxidase (GPx), and catalase) and nonenzymatic antioxidants (e.g., ascorbic acid (vitamin C), tocopherol (vitamin E)) but more reactive oxygen species (ROS) (e.g., superoxide anion radicals, hydroxyl radicals, and hydrogen peroxide) [4]. An imbalance could result from the above causing damage to the body cell [5-8] and other health challenges [9]. Preventive medicine has been immensely enhanced by the use of these natural plant antioxidants. Plants contain lots of free radical scavenging molecules some of which include alkaloids, amines, betalains, vitamins, terpenoids, phenolic acids, lignins, stilbenes, and tannins 
as well as other secondary metabolites with high level of antioxidant activity [4]. Most phytochemicals are antioxidant agents which essentially reduce the damages caused in tissue during physiological processes. This research is aimed at determining the qualitative and quantitative phytochemical components in Nigerian softwood as indices of producing plant secondary metabolites which have medicinal values as well as application in industries.

\section{Materials and Methods}

2.1. Materials. Soft wood samples were locally collected at saw mill in different states in Nigeria and identified as reported elsewhere $[10,11]$.

2.2. Wood Sample Preparation. Twenty-four identified softwoods were prepared before analysis in a finely grounded chip form as reported by Ejikeme et al. [11].

2.3. Phytochemical Constituents of Nigerian Softwood Samples. Methodologies for the determination of phytochemical used in this research were adapted from those reported by Keay et al. [10] and Ejikeme et al. [11], respectively.

\subsection{Qualitative Analysis of the Phytochemicals of the Wood Sample}

2.4.1. Test for Tannins. Analysis used was the method reported by Ejikeme et al. [11]. Each wood powder sample $(0.30 \mathrm{~g})$ was weighed into a test tube and boiled for 10 minutes in a water bath containing $30 \mathrm{~cm}^{3}$ of water. Filtration was carried out after boiling using number $42(125 \mathrm{~mm})$ Whatman filter paper. To $5 \mathrm{~cm}^{3}$ of the filtrate was added 3 drops of $0.1 \%$ ferric chloride. A brownish green or a blue black colouration showed positive test.

2.4.2. Test for Phlobatannins. Analytical method is according to Ejikeme et al. [11]. To each sample $(0.30 \mathrm{~g})$ weighed into a beaker was added $30 \mathrm{~cm}^{3}$ of distilled water. After 24 hours of extraction, aqueous extract $\left(10 \mathrm{~cm}^{3}\right)$ of each wood sample was boiled with $5 \mathrm{~cm}^{3}$ of $1 \%$ aqueous hydrochloric acid. Deposit of red precipitate showed positive test.

2.4.3. Test for Saponin. Methodology is as reported by Ejikeme et al. [11]. Distilled water $\left(30 \mathrm{~cm}^{3}\right)$ was added to wood powder samples $(0.30 \mathrm{~g})$ and boiled for 10 minutes in water bath and filtered using Whatman filter paper number $42(125 \mathrm{~mm})$. A mixture of distilled water $\left(5 \mathrm{~cm}^{3}\right)$ and filtrate $\left(10 \mathrm{~cm}^{3}\right)$ was agitated vigorously for a stable persistent froth. The formation of emulsion on addition of three drops of olive oil showed positive result.

2.4.4. Test for Steroid. Analytical method used is according to Ejikeme et al. [11]. Each sample $(0.30 \mathrm{~g})$ weighed into a beaker was mixed with $20 \mathrm{~cm}^{3}$ of ethanol; the component was extracted for 2 hours. To the ethanolic extract of each sample $\left(5 \mathrm{~cm}^{3}\right)$ was added $2 \mathrm{~cm}^{3}$ acetic anhydride followed with $2 \mathrm{~cm}^{3}$ of concentrated tetraoxosulphate (VI) acid. A violet to blue or green colour change in sample(s) indicates the presence of steroids.

2.4.5. Test for Terpenoids. Methodology is as reported by Ejikeme et al. [11]. Each wood powder sample $(0.30 \mathrm{~g})$ was weighed into a beaker and extracted with $30 \mathrm{~cm}^{3}$ and component extracted for 2 hours. A mixture of chloroform $\left(2 \mathrm{~cm}^{3}\right)$ and concentrated tetraoxosulphate (VI) acid $\left(3 \mathrm{~cm}^{3}\right)$ was added to $5 \mathrm{~cm}^{3}$ of each extract to form a layer. The presence of a reddish brown colouration at the interface shows positive results for the presence of terpenoids.

2.4.6. Test for Flavonoids. The test for flavonoid adopted is as reported by Sofowara [12] and Harborne [2]. Each sample $(0.30 \mathrm{~g})$ weighed into a beaker was extracted with $30 \mathrm{~cm}^{3}$ of distilled water for 2 hours and filtered with Whatman filter paper number $42(125 \mathrm{~mm})$. To $10 \mathrm{~cm}^{3}$ of the aqueous filtrate of each wood extract was added $5 \mathrm{~cm}^{3}$ of $1.0 \mathrm{M}$ dilute ammonia solution followed by the addition of $5 \mathrm{~cm}^{3}$ of concentrated tetraoxosulphate (VI) acid. Appearance of yellow colouration which disappeared on standing shows the presence of flavonoids.

2.4.7. Test for Alkaloids. Test for flavonoid used is as reported by Hikino et al. [13]. Extraction of component from 2 grams of each wood powder sample was carried out using 5\% tetraoxosulphate (VI) acid $\left(\mathrm{H}_{2} \mathrm{SO}_{4}\right)\left(20 \mathrm{~cm}^{3}\right)$ in $50 \%$ ethanol by boiling for 2 minutes and filtered through Whatman filter paper number $42(125 \mathrm{~mm})$. The filtrate was made alkaline using $5 \mathrm{~cm}^{3}$ of $28 \%$ ammonia solution $\left(\mathrm{NH}_{3}\right)$ in a separating funnel. Equal volume of chloroform $\left(5.0 \mathrm{~cm}^{3}\right)$ was used in further solution extraction in which chloroform solution was extracted with two $5 \mathrm{~cm}^{3}$ portions of $1.0 \mathrm{M}$ dilute tetraoxosulphate (VI) acid. This final acid extract was then used to carry out the following test: $0.5 \mathrm{~cm}^{3}$ of Dragendorff's reagent (Bismuth potassium iodide solution) was mixed with $2 \mathrm{~cm}^{3}$ of acid extract and precipitated orange colour infers the presence of alkaloid.

2.4.8. Test for Glycoside. Glycoside test was conducted according to the method reported by Hikino et al. [13]. To $2.00 \mathrm{~g}$ of each sample was added $20 \mathrm{~cm}^{3}$ of water, heated for 5 minutes on a water bath and filtered through Gem filter paper $(12.5 \mathrm{~cm})$. The following tests were carried out with the filtrate:

(a) $0.2 \mathrm{~cm}^{3}$ of Fehling's solutions $\mathrm{A}$ and $\mathrm{B}$ was mixed with $5 \mathrm{~cm}^{3}$ of the filtrate until it became alkaline (tested with litmus paper). A brick-red colouration on heating showed a positive result.

(b) Instead of water, $15 \mathrm{~cm}^{3}$ of $1.0 \mathrm{M}$ sulphuric acid was used to repeat the above test and the quantity of precipitate obtained compared with that of (a) above. High precipitate content indicates the presence of glycoside while low content shows the absence of glycoside. 


\subsection{Quantitative Determination of Phytochemical Constituents of Woods}

2.5.1. Tannin. Analytical method for quantitative determination of tannin was according to Amadi et al. [14] and Ejikeme et al. [11]. By dissolving $50 \mathrm{~g}$ of sodium tungstate $\left(\mathrm{Na}_{2} \mathrm{WO}_{4}\right)$ in $37 \mathrm{~cm}^{3}$ of distilled water, Folin-Denis reagent was made. To the reagent prepared above, $10 \mathrm{~g}$ of phosphomolybdic acid $\left(\mathrm{H}_{3} \mathrm{PMo}_{12} \mathrm{O}_{40}\right)$ and $25 \mathrm{~cm}^{3}$ of orthophosphoric acid $\left(\mathrm{H}_{3} \mathrm{PO}_{4}\right)$ were added. Two-hour reflux of the mixture was carried out, cooled, and diluted to $500 \mathrm{~cm}^{3}$ with distilled water. One gram of each wood powder (sample) in a conical flask was added to $100 \mathrm{~cm}^{3}$ of distilled water. This was boiled gently for 1 hour on an electric hot plate and filtered using number $42(125 \mathrm{~mm})$ Whatman filter paper in a $100 \mathrm{~cm}^{3}$ volumetric flask. Addition of $5.0 \mathrm{~cm}^{3}$ Folin-Denis reagent and $10 \mathrm{~cm}^{3}$ of saturated $\mathrm{Na}_{2} \mathrm{CO}_{3}$ solution into $50 \mathrm{~cm}^{3}$ of distilled water and $10 \mathrm{~cm}^{3}$ of diluted extract (aliquot volume) was carried out after being pipetted into a $100 \mathrm{~cm}^{3}$ conical flask for colour development. The solution was allowed to stand for 30 minutes in a water bath at a temperature of $25^{\circ} \mathrm{C}$ after thorough agitation. With the aid of a Spectrum Lab 23A spectrophotometer optical density was measured at $700 \mathrm{~nm}$ and compared on a standard tannic acid curve. Dissolution of $0.20 \mathrm{~g}$ of tannic acid in distilled water and dilution to $200 \mathrm{~cm}^{3}$ mark $\left(1 \mathrm{mg} / \mathrm{cm}^{3}\right)$ were used to obtain tannic standard curve. Varying concentrations $\left(0.2-1.0 \mathrm{mg} / \mathrm{cm}^{3}\right)$ of the standard tannic acid solution were pipetted into five different test tubes to which Folin-Denis reagent $\left(5 \mathrm{~cm}^{3}\right)$ and saturated $\mathrm{Na}_{2} \mathrm{CO}_{3}\left(10 \mathrm{~cm}^{3}\right)$ solution were added and made up to the $100 \mathrm{~cm}^{3}$ mark with distilled water. The solution was left to stand for 30 minutes in a water bath at $25^{\circ} \mathrm{C}$. Optical density was ascertained at $700 \mathrm{~nm}$ with the aid of a Spectrum Lab 23A spectrophotometer. Optical density (absorbance) versus tannic acid concentration was plotted.

The following formula was used in the calculation:

$$
\begin{aligned}
& \text { Tannic acid }\left(\frac{\mathrm{mg}}{100 \mathrm{~g}}\right) \\
& =\frac{C \times \text { extract volume } \times 100}{\text { Aliquot volume } \times \text { weight of sample }},
\end{aligned}
$$

where $C$ is concentration of tannic acid read off the graph.

2.5.2. Determination of Alkaloids. Quantitative determination of alkaloid was according to the methodology by Harborne [2]. Exactly $200 \mathrm{~cm}^{3}$ of $10 \%$ acetic acid in ethanol was added to each wood powder sample $(2.50 \mathrm{~g})$ in a $250 \mathrm{~cm}^{3}$ beaker and allowed to stand for 4 hours. The extract was concentrated on a water bath to one-quarter of the original volume followed by addition of 15 drops of concentrated ammonium hydroxide dropwise to the extract until the precipitation was complete immediately after filtration. After 3 hours of mixture sedimentation, the supernatant was discarded and the precipitates were washed with $20 \mathrm{~cm}^{3}$ of $0.1 \mathrm{M}$ of ammonium hydroxide and then filtered using Gem filter paper $(12.5 \mathrm{~cm})$. Using electronic weighing balance Model B218 , the residue was dried in an oven and the percentage of alkaloid is expressed mathematically as

$$
\% \text { Alkaloid }=\frac{\text { Weight of alkaloid }}{\text { Weight of sample }} \times 100 \text {. }
$$

2.5.3. Determination of Flavonoid. Flavonoid determination was by the method reported by Ejikeme et al. [11] and Boham and Kocipai [15]. Exactly $50 \mathrm{~cm}^{3}$ of $80 \%$ aqueous methanol added was added to $2.50 \mathrm{~g}$ of sample in a $250 \mathrm{~cm}^{3}$ beaker, covered, and allowed to stand for 24 hours at room temperature. After discarding the supernatant, the residue was reextracted (three times) with the same volume of ethanol. Whatman filter paper number $42(125 \mathrm{~mm})$ was used to filter whole solution of each wood sample. Each wood sample filtrate was later transferred into a crucible and evaporated to dryness over a water bath. The content in the crucible was cooled in a desiccator and weighed until constant weight was obtained. The percentage of flavonoid was calculated as

$$
\% \text { Flavonoid }=\frac{\text { Weight of flavonoid }}{\text { Weight of sample }} \times 100 \text {. }
$$

2.5.4. Determination of Saponin. Saponin quantitative determination was carried out using the method reported by Ejikeme et al. [11] and Obadoni and Ochuko [16]. Exactly $100 \mathrm{~cm}^{3}$ of $20 \%$ aqueous ethanol was added to 5 grams of each wood powder sample in a $250 \mathrm{~cm}^{3}$ conical flask. The mixture was heated over a hot water bath for 4 hours with continuous stirring at a temperature of $55^{\circ} \mathrm{C}$. The residue of the mixture was reextracted with another $100 \mathrm{~cm}^{3}$ of $20 \%$ aqueous ethanol after filtration and heated for 4 hours at a constant temperature of $55^{\circ} \mathrm{C}$ with constant stirring. The combined extract was evaporated to $40 \mathrm{~cm}^{3}$ over water bath at $90^{\circ} \mathrm{C} .20 \mathrm{~cm}^{3}$ of diethyl ether was added to the concentrate in a $250 \mathrm{~cm}^{3}$ separator funnel and vigorously agitated from which the aqueous layer was recovered while the ether layer was discarded. This purification process was repeated twice. $60 \mathrm{~cm}^{3}$ of $\mathrm{n}$-butanol was added and extracted twice with $10 \mathrm{~cm}^{3}$ of $5 \%$ sodium chloride. After discarding the sodium chloride layer the remaining solution was heated in a water bath for 30 minutes, after which the solution was transferred into a crucible and was dried in an oven to a constant weight. The saponin content was calculated as a percentage:

$$
\% \text { Saponin }=\frac{\text { Weight of saponin }}{\text { Weight of sample }} \times 100 \text {. }
$$

2.5.5. Determination of Oxalate. Oxalate quantitative determination was carried out using the method reported by Ejikeme et al. [11] and Munro and Bassir [17]. Exactly $20 \mathrm{~cm}^{3}$ of $0.3 \mathrm{M} \mathrm{HCl}$ in each wood powder sample $(2.50 \mathrm{~g})$ was extracted three (3) times by warming at a temperature of $50^{\circ} \mathrm{C}$ for 1 hour with constant stirring using a magnetic stirrer. For oxalate estimation, $1.0 \mathrm{~cm}^{3}$ of $5 \mathrm{M}$ ammonium hydroxide was added to $5.0 \mathrm{~cm}^{3}$ of extract to ensure alkalinity. Addition of 2 drops of phenolphthalein indicator, 3 drops of glacial 
acetic acid, and $1.0 \mathrm{~cm}^{3}$ of $5 \%$ calcium chloride to make the mixture acidic before standing for 3 hours was followed by centrifugation at $3000 \mathrm{rpm}$ for 15 minutes. After discarding the supernatant, the precipitate was washed three times using hot water by mixing thoroughly each time centrifugation. Then, to each tube, $2.0 \mathrm{~cm}^{3}$ of $3 \mathrm{M}$ tetraoxosulphate (VI) acid was added and the precipitate dissolved by warming in a water bath at $70^{\circ} \mathrm{C}$. Freshly prepared $0.01 \mathrm{M}$ potassium permanganate $\left(\mathrm{KMnO}_{4}\right)$ was titrated against the content of each tube at room temperature until the first pink colour appears throughout the solution. The solution was allowed to stand until it returned colourless, after which it was warmed on an electric hot plate at $70^{\circ} \mathrm{C}$ for 3 minutes, and retitrated again until a pink colour appears and persists for at least 30 seconds.

Titration reaction of oxalate in sample was calculated as

$$
\begin{aligned}
\mathrm{C}_{2} \mathrm{O}^{2-}{ }_{4}+8 \mathrm{H}^{+}+\mathrm{MnO}^{2-}{ }_{4} & =2 \mathrm{CO}_{2}+4 \mathrm{H}_{2} \mathrm{O}+\mathrm{Mn}^{2+} \\
\text { Ratio of reacting ions } & =1: 1 \\
\text { From } M_{1} V_{1} & =M_{2} V_{2},
\end{aligned}
$$

where $M_{1}$ is molarity of $\mathrm{KMnO}_{4}, M_{2}$ is molarity of extract (oxalate), $V_{1}$ is volume of extract (oxalate), and $V_{2}$ is volume of $\mathrm{KMnO}_{4}$ (Titre Value).

$$
\begin{aligned}
& \text { Molecular Weight of } \mathrm{CaCO}_{3}=100 \\
& \text { Weight of oxalate in titre }=M_{2} \times \text { molecular weight } \\
& \quad=X g
\end{aligned}
$$$$
\text { Weight of oxalate in titrand } 2 \mathrm{Cm}^{3}=\frac{X g}{1000} \times 2=Y
$$$$
100 \mathrm{Cm}^{3} \text { of oxalate extract will contain }=\frac{Y}{2.5} \times 100 \mathrm{~g}
$$$$
=W
$$

$\%$ oxalate composition $\mathrm{g} / 100 \mathrm{~g}=\frac{W}{2.5} \times \frac{100}{1}$.

2.5.6. Determination of Cyanogenic Glycoside. Cyanogenic glycoside quantitative determination methodology used in this research is that by Amadi et al. [14] as reported by Ejikeme et al. [11]. It was weighed into a $250 \mathrm{~cm}^{3}$ round bottom flask and about $200 \mathrm{~cm}^{3}$ of distilled water was added to one gram of each dry wood powder sample and allowed to stand for 2 hours for autolysis to occur. Full distillation was carried out in a $250 \mathrm{~cm}^{3}$ conical flask containing $20 \mathrm{~cm}^{3}$ of $2.5 \% \mathrm{NaOH}$ (sodium hydroxide) in the sample after adding an antifoaming agent (tannic acid). Cyanogenic glycoside $\left(100 \mathrm{~cm}^{3}\right), 8 \mathrm{~cm}^{3}$ of $6 \mathrm{M} \mathrm{NH}_{4} \mathrm{OH}$ (ammonium hydroxide), and $2 \mathrm{~cm}^{3}$ of $5 \% \mathrm{KI}$ (potassium iodide) were added to the distillate(s), mixed, and titrated with $0.02 \mathrm{M} \mathrm{AgNO}_{3}$ (silver nitrate) using a microburette against a black background. Turbidity which was continuous indicates the end point.
Content of cyanogenic glycoside in the sample was calculated as

$$
\begin{aligned}
& \text { Cyanogenic glycoside }\left(\frac{\mathrm{mg}}{100 \mathrm{~g}}\right) \\
& \begin{aligned}
= & \text { Titre Value }\left(\mathrm{Cm}^{3}\right) \times 1.08 \times \text { exact volume } \\
& \quad \times 100 .
\end{aligned}
\end{aligned}
$$

2.5.7. Determination of Percentage Lipid. Into a thimble connected to a soxhlet extractor chamber with a preweighed flat bottom was added each dry wood powder $(2.50 \mathrm{~g})$ and connected to a condenser. Petroleum ether $(100 \mathrm{~mL})$ enough to cause a reflux was added to the flask and the lipid from the wood sample was extracted for 3 hours by heating on an electric hot plate at $50^{\circ} \mathrm{C}$. The extractant (petroleum ether) was distilled off and the lipid recovered by cooling the flask in a dessicator and its value calculated by reweighed flask and content. This methodology for lipid quantitative analysis is reported elsewhere [18]. The calculated percentage of lipid content was thus

$$
\% \text { Lipid }=\frac{\text { Weight of Lipid }}{\text { Weight of Sample }} \times 100 .
$$

2.5.8. Determination of Phenols. Defatting of $2 \mathrm{~g}$ wood powder sample was carried out for 2 hours in $100 \mathrm{~cm}^{3}$ of ether using a soxhlet apparatus. The defatted sample $(0.50 \mathrm{~g})$ was boiled for 15 minutes with $50 \mathrm{~cm}^{3}$ of ether for the extraction of the phenolic components. Exactly $10 \mathrm{~cm}^{3}$ of distilled water, $2 \mathrm{~cm}^{3}$ of $0.1 \mathrm{~N}$ ammonium hydroxide solution, and $5 \mathrm{~cm}^{3}$ of concentrated amyl alcohol were also added to $5 \mathrm{~cm}^{3}$ of the extract and left to react for 30 minutes for colour development. The optical density was measured at $505 \mathrm{~nm}$. $0.20 \mathrm{~g}$ of tannic acid was dissolving in distilled water and diluted to $200 \mathrm{~mL}$ mark $\left(1 \mathrm{mg} / \mathrm{cm}^{3}\right)$ in preparation for phenol standard curve. Varying concentrations $\left(0.2-1.0 \mathrm{mg} / \mathrm{cm}^{3}\right)$ of the standard tannic acid solution were pipetted into five different test tubes to which $2 \mathrm{~cm}^{3}$ of $\mathrm{NH}_{3} \mathrm{OH}, 5 \mathrm{~cm}^{3}$ of amyl alcohol, and $10 \mathrm{~cm}^{3}$ of water were added. The solution was made up to $100 \mathrm{~cm}^{3}$ volume and left to react for 30 minutes for colour development. The optical density was determined at $505 \mathrm{~nm}$ [10].

\section{Results}

Table 1 is a list of the various softwoods whose powdered mills were examined. Their local names in Igbo, Hausa, and Yoruba as well as where they are found in Nigeria are clearly shown. Qualitative determination of phytochemicals as seen in Table 2 showed various plant secondary metabolites in which there was no heavy presence of alkaloid in all the softwood timber powder examined. However, there was slight presence of alkaloid in all of them. Heavy presence of flavonoid was noted only in Barteria nigritiana; other softwoods showed mere presence of it. Phlobatannin was 
TABLE 1: Table of the botanical and local names as well as location of various Nigerian softwoods.

\begin{tabular}{|c|c|c|c|c|c|c|c|}
\hline $\mathrm{S} / \mathrm{N}$ & $\begin{array}{c}\text { Wood sample } \\
\text { (botanical name) }\end{array}$ & Classification & Botanical families & Igbo & Yoruba & Hausa & Location \\
\hline 1 & Monodora tenuifolia & Softwood & Annonaceae & Ehuru ofia & Lakesin & Guyiyadanmiya & Port Harcourt \\
\hline 2 & Moringa oleifera & Softwood & Moringaceae & Okwe oyibo & Ewe igbale & Zogalla gandi & Lagos, Ibadan \\
\hline 3 & Protea elliottii & Softwood & Proteaceae & Okwo & Dehinbolorun & Halshena & Nsukka \\
\hline 4 & Barteria nigritiana & Softwood & - & Ukwoifia & Oko & Idon zakara & Nsukka, Enugu \\
\hline 5 & Anogeissus leiocarpus & Softwood & Combretaceae & Atara & Egba & Marike & Onitsha, Awka \\
\hline 6 & $\begin{array}{l}\text { Allanblackia } \\
\text { floribunda }\end{array}$ & Softwood & Guttiferae & Egba & Orogbo & Guthiferae eku & Calabar, Ikom \\
\hline 7 & Glyphaea brevis & Softwood & Tiliaceae & Anyasu alo & Eso, shishi & $\begin{array}{l}\text { Bolukonu } \\
\text { kanana }\end{array}$ & Calabar \\
\hline 8 & Sterculia oblonga & Softwood & Sterculiaceae & Ebenebe & Aworlwo & Kukuki & Ibadan \\
\hline 9 & Uapaca guineensis & Softwood & Euphorbiaceae & Obia & - & Wawan kurmi & Onitsha \\
\hline 10 & $\begin{array}{c}\text { Amphimas } \\
\text { pterocarpoides }\end{array}$ & Softwood & Leguminosae & Awo & Ogiya & Wawan kurmii & Umuahia, Ikom \\
\hline 11 & Albizia adianthifolia & Softwood & Leguminosae-Mimosoideae & Avu & Anyimebona & Gamba & Enugu, Nsukka \\
\hline 12 & Dichapetalum barteri & Softwood & Dichapetalaceae & Ngbu ewu & Ira & Kirni & Onitsha, Agulu \\
\hline 13 & Afzelia bipindensis & Softwood & Fabaceae & Aja & Olutoko & Rogon daji & Benin \\
\hline 14 & Afzelia bella & Softwood & Fabaceae & Uzoaka & Peanut & Epa & Owerri, Orlu \\
\hline 15 & Dichrostachys cinerea & Softwood & Fabaceae & Amiogwu & Kara & Dundu & Onitsha \\
\hline 16 & $\begin{array}{l}\text { Pentaclethra } \\
\text { macrophylla }\end{array}$ & Softwood & Leguminosae & Ugba & Apara & Kiriya & Onitsha \\
\hline 17 & Tetrapleura tetraptera & Softwood & Leguminosae-Mimosoideae & Oshosho & Aridan & Dawo & $\begin{array}{l}\text { Onitsha, } \\
\text { Akpaka }\end{array}$ \\
\hline 18 & Afrormosia laxiflora & Softwood & Leguminosae-Papilionoideae & Abua ocha & Shedun & Idon zakara & Sokoto \\
\hline 19 & Sacoglottis gabonensis & Softwood & Rhizophoraceae & Nche & Atala & Chediya & Rivers \\
\hline 20 & Cassipourea barteri & Softwood & Lecythidaceae & Itobo & Itobo & Odu & Eket \\
\hline 21 & $\begin{array}{l}\text { Combretodendron } \\
\text { macrocarpum }\end{array}$ & Softwood & Ochnaceae & Anwushi & Anwushi & Akasun & Udi, Owerri \\
\hline 22 & Cordia millenii & Softwood & Meliaceae & Okwe & Okwe & - & Owerri, Onitsha \\
\hline 23 & Khaya ivorensis & Softwood & Bignoniaceae & Ono & Oganwo & Madachi & Calabar \\
\hline 24 & Kaempferia galanga & Softwood & Zingiberaceae & Shanty & - & - & Enugu \\
\hline
\end{tabular}

absent in all the softwoods examined. Some presence of terpenoid was observed in some with others not having any presence of the metabolite in them (Table 2). Anogeissus leiocarpus, Dichrostachys cinerea, Afrormosia laxiflora, Sacoglottis gabonensis, Khaya ivorensis, and Kaempferia galanga all showed heavy presence of saponin. With the exception of Protea elliottii and Barteria nigritiana, other softwoods had slight presence of saponin. The presence of tannin was observed heavily in the following: Protea elliottii, Glyphaea brevis, Uapaca guineensis, Albizia adianthifolia, Dichapetalum barteri, Afzelia bella, Tetrapleura tetraptera, Cordia millenii, and Combretodendron macrocarpum (this was corroborated by Itoandon et al. [19]). Moringa oleifera, Barteria nigritiana, Anogeissus leiocarpus, Allanblackia floribunda, Albizia adianthifolia, Afzelia bipindensis, Pentaclethra macrophylla, and Cassipourea barteri were seen to contain heavy content of steroids. Glycoside was heavily present in Moringa oleifera, Afzelia bipindensis, Tetrapleura tetraptera, Combretodendron macrocarpum, and Cordia millenii.
Quantitative analysis (Table 3) showed that generally small quantities of tannin were found in all the Nigerian softwoods examined with the highest quantities obtained in Sterculia oblonga (1240 mg/100 g), Barteria nigritiana $(1230 \mathrm{mg} / 100 \mathrm{~g})$, Albizia adianthifolia (1190 mg/100 g), Afzelia bella $(1160 \mathrm{mg} / 100 \mathrm{~g})$, and Combretodendron macrocarpum $(1150 \mathrm{mg} / 100 \mathrm{~g})$. The highest quantities of alkaloid were obtained in Cordia millenii (11.2\%), Sterculia oblonga (10.4\%), Amphimas pterocarpoides (9.8\%), and Khaya ivorensis (9.4\%). Barteria nigritiana (14.2\%), Moringa oleifera (12.2\%) (flavonoid value higher than obtained elsewhere [20] from methanolic extract of Moringa oleifera leaf (31.73 \pm $2.66 \mathrm{mg} / \mathrm{g})$ and seed $(20.73 \pm 4.16 \mathrm{mg} / \mathrm{g}))$, Combretodendron macrocarpum (9.5\%), Cordia millenii (8.2\%), Afrormosia laxiflora, and Sacoglottis gabonensis (8\%) contain the highest quantities of flavonoids. Quantities of saponin in Anogeissus leiocarpus (12.5\%) (comparably higher to value $(89.5 \pm 0.57 \mathrm{mg} / \mathrm{dL})$ obtained elsewhere [21] from stem barks of plant), Dichrostachys cinerea (9.8\%), Afzelia 
TABLE 2: Table of the qualitative determination of the phytochemical components of Nigerian softwoods.

\begin{tabular}{|c|c|c|c|c|c|c|c|c|c|}
\hline $\mathrm{S} / \mathrm{N}$ & $\begin{array}{c}\text { Wood sample } \\
\text { (botanical name) }\end{array}$ & Alkaloids & Flavonoids & Glycoside & Phlobatannins & Tannins & Terpenoids & Saponins & Steroids \\
\hline 1 & $\begin{array}{c}\text { Monodora } \\
\text { tenuifolia }\end{array}$ & ++ & + & ++ & - & ++ & + & + & ++ \\
\hline 2 & Moringa oleifera & ++ & ++ & +++ & - & ++ & + & + & +++ \\
\hline 3 & Protea elliottii & + & + & ++ & - & +++ & + & - & ++ \\
\hline 4 & $\begin{array}{c}\text { Barteria } \\
\text { nigritiana }\end{array}$ & + & +++ & ++ & - & ++ & - & - & +++ \\
\hline 5 & $\begin{array}{l}\text { Anogeissus } \\
\text { leiocarpus }\end{array}$ & + & + & - & - & ++ & + & +++ & +++ \\
\hline 6 & $\begin{array}{l}\text { Allanblackia } \\
\text { floribunda }\end{array}$ & + & + & ++ & - & - & ++ & ++ & +++ \\
\hline 7 & Glyphaea brevis & + & + & ++ & - & +++ & + & + & + \\
\hline 8 & Sterculia oblonga & ++ & - & ++ & - & ++ & + & + & - \\
\hline 9 & Uapaca guineensis & + & ++ & ++ & - & +++ & ++ & + & - \\
\hline 10 & $\begin{array}{c}\text { Amphimas } \\
\text { pterocarpoides }\end{array}$ & ++ & + & ++ & - & ++ & + & + & - \\
\hline 11 & $\begin{array}{c}\text { Albizia } \\
\text { adianthifolia }\end{array}$ & + & + & + & - & +++ & - & + & +++ \\
\hline 12 & $\begin{array}{c}\text { Dichapetalum } \\
\text { barteri }\end{array}$ & + & + & ++ & - & +++ & + & + & - \\
\hline 13 & $\begin{array}{c}\text { Afzelia } \\
\text { bipindensis }\end{array}$ & + & + & +++ & - & ++ & ++ & ++ & +++ \\
\hline 14 & Afzelia bella & + & + & + & - & +++ & - & ++ & + \\
\hline 15 & $\begin{array}{l}\text { Dichrostachys } \\
\text { cinerea }\end{array}$ & + & + & ++ & - & + & + & +++ & - \\
\hline 16 & $\begin{array}{l}\text { Pentaclethra } \\
\text { macrophylla }\end{array}$ & + & + & ++ & - & - & - & + & +++ \\
\hline 17 & $\begin{array}{c}\text { Tetrapleura } \\
\text { tetraptera }\end{array}$ & + & + & +++ & - & +++ & + & + & ++ \\
\hline 18 & $\begin{array}{l}\text { Afrormosia } \\
\text { laxiflora }\end{array}$ & + & + & ++ & - & + & + & +++ & - \\
\hline 19 & $\begin{array}{l}\text { Sacoglottis } \\
\text { gabonensis }\end{array}$ & + & + & ++ & - & + & + & +++ & - \\
\hline 20 & $\begin{array}{c}\text { Cassipourea } \\
\text { barteri }\end{array}$ & + & + & ++ & - & - & - & + & +++ \\
\hline 21 & $\begin{array}{c}\text { Combretodendron } \\
\text { macrocarpum }\end{array}$ & + & + & +++ & - & +++ & + & + & ++ \\
\hline 22 & Cordia millenii & + & + & +++ & - & +++ & + & + & ++ \\
\hline 23 & Khaya ivorensis & + & + & ++ & - & + & + & +++ & - \\
\hline
\end{tabular}

Heavily present: +++; slightly present: ++; present: +; absent: - .

bipindensis (6.8\%), and Sacoglottis gabonensis (6.6\%) were highest among the softwoods analyzed. Highest quantities of oxalate were found in Combretodendron macrocarpum (5.84 g/100 g), Glyphaea brevis (3.55 g/100 g), Cordia millenii (3.05 g/100 g), Moringa oleifera (3.2 g/100 g), and Barteria nigritiana $(2.91 \mathrm{~g} / 100 \mathrm{~g})$. Cyanogenic glycoside in Pentaclethra macrophylla (890 mg/100 g), Moringa oleifera (880 mg/100 g), Tetrapleura tetraptera (890 mg/100 g), Protea elliottii ( $810 \mathrm{mg} /$ $100 \mathrm{~g})$, and Cassipourea barteri $(860 \mathrm{mg} / 100 \mathrm{~g}$ ) was higher than the other softwoods. The highest quantities of phenol found in Sacoglottis gabonensis (4.68 mg/g), Pentaclethra macrophylla (4.04 mg/g), Moringa oleifera $(3.58 \mathrm{mg} / \mathrm{g})$, and Anogeissus leiocarpus (3.40 mg/g) were comparable but slightly lower than value $(5.20 \pm 0.17 \mathrm{mg} / \mathrm{dL})$ obtained elsewhere [21] in stem bark of Anogeissus leiocarpus. Anogeissus leiocarpus (8\%), Kaempferia galanga (7.2\%), Dichrostachys cinerea (6.8\%), and Allanblackia floribunda (6.4\%) contained highest quantities of lipids among the softwoods examined.

\section{Discussion}

Softwoods such as Sterculia oblonga, Barteria nigritiana, Albizia adianthifolia, Afzelia bella, and Combretodendron macrocarpum, whose qualitative and quantitative determination in this study were shown to contain tannins, could be exploited for their industrial usage. Tannin is one of the 
TABLE 3: Table of quantitative phytochemicals of Nigerian softwoods.

\begin{tabular}{|c|c|c|c|c|c|c|c|c|c|}
\hline $\mathrm{S} / \mathrm{N}$ & $\begin{array}{c}\text { Wood sample } \\
\text { (botanical name) }\end{array}$ & $\begin{array}{c}\text { Tannin } \\
(\mathrm{mg} / 100 \mathrm{~g})\end{array}$ & $\begin{array}{l}\text { Alkaloid } \\
\quad(\%)\end{array}$ & $\begin{array}{l}\text { Flavonoid } \\
\quad(\%)\end{array}$ & $\begin{array}{l}\text { Saponin } \\
(\%)\end{array}$ & $\begin{array}{l}\text { Oxalate } \\
(\mathrm{g} / 100 \mathrm{~g})\end{array}$ & $\begin{array}{c}\text { Cyanogenic } \\
\text { glycoside } \\
(\mathrm{mg} / 100 \mathrm{~g})\end{array}$ & $\begin{array}{l}\text { Phenol } \\
\text { (mg/g) }\end{array}$ & $\begin{array}{l}\text { Lipid } \\
(\%)\end{array}$ \\
\hline 1 & $\begin{array}{l}\text { Monodora } \\
\text { tenuifolia }\end{array}$ & 900 & 8.6 & 7.4 & 4.4 & 0.45 & 680 & 1.82 & 3.6 \\
\hline 2 & Moringa oleifera & 930 & 8.0 & 12.2 & 4.2 & 3.2 & 880 & 3.58 & 3.2 \\
\hline 3 & Protea elliottii & 1030 & 7.6 & 5.4 & 1.6 & 1.31 & 810 & 3.14 & 0.4 \\
\hline 4 & Barteria nigritiana & 1230 & 8.4 & 14.2 & 1.6 & 2.91 & 660 & 1.90 & 2.4 \\
\hline 5 & $\begin{array}{l}\text { Anogeissus } \\
\text { leiocarpus }\end{array}$ & 920 & 4.8 & 3.0 & 12.5 & 0.58 & 340 & 3.40 & 8.0 \\
\hline 6 & $\begin{array}{l}\text { Allanblackia } \\
\text { floribunda }\end{array}$ & 690 & 1.6 & 4.6 & 5.2 & 3.05 & 650 & 1.58 & 6.4 \\
\hline 7 & Glyphaea brevis & 980 & 4.8 & 7.2 & 4.4 & 3.55 & 730 & 2.04 & 4.0 \\
\hline 8 & Sterculia oblonga & 1240 & 10.4 & 3.4 & 4.0 & 1.31 & 620 & 1.66 & 4.4 \\
\hline 9 & Uapaca guineensis & 1120 & 8.0 & 9.2 & 4.4 & 0.8 & 700 & 1.66 & 4.8 \\
\hline 10 & $\begin{array}{c}\text { Amphimas } \\
\text { pterocarpoides }\end{array}$ & 870 & 9.8 & 7.5 & 3.6 & 0.69 & 410 & 0.86 & 1.2 \\
\hline 11 & $\begin{array}{c}\text { Albizia } \\
\text { adianthifolia }\end{array}$ & 1190 & 8.0 & 7.2 & 2.2 & 2.56 & 440 & 0.49 & 1.6 \\
\hline 12 & $\begin{array}{l}\text { Dichapetalum } \\
\text { barteri }\end{array}$ & 1110 & 6.0 & 4.0 & 3.0 & 1.02 & 500 & 0.04 & 2.8 \\
\hline 13 & Afzelia bipindensis & 930 & 7.6 & 2.0 & 6.8 & 2.0 & 760 & 0.26 & 3.6 \\
\hline 14 & Afzelia bella & 1160 & 5.6 & 7.0 & 5.8 & 1.83 & 730 & 0.18 & 6.0 \\
\hline 15 & $\begin{array}{l}\text { Dichrostachys } \\
\text { cinerea }\end{array}$ & 840 & 4.4 & 1.8 & 9.8 & 2.21 & 680 & 1.76 & 6.8 \\
\hline 16 & $\begin{array}{l}\text { Pentaclethra } \\
\text { macrophylla }\end{array}$ & 690 & 6.4 & 4.0 & 4.4 & 1.6 & 890 & 4.04 & 4.0 \\
\hline 17 & $\begin{array}{l}\text { Tetrapleura } \\
\text { tetraptera }\end{array}$ & 1090 & 4.0 & 4.4 & 3.6 & 1.73 & 860 & 1.66 & 1.2 \\
\hline 18 & $\begin{array}{l}\text { Afrormosia } \\
\text { laxiflora }\end{array}$ & 710 & 8.8 & 8.0 & 4.2 & 0.8 & 520 & 1.74 & 3.6 \\
\hline 19 & $\begin{array}{l}\text { Sacoglottis } \\
\text { gabonensis }\end{array}$ & 1090 & 8.0 & 8.0 & 6.6 & 0.21 & 300 & 4.68 & 4.4 \\
\hline 20 & Cassipourea barteri & 990 & 9.0 & 4.8 & 3.8 & 0.73 & 860 & 2.38 & 2.8 \\
\hline 21 & $\begin{array}{l}\text { Combretodendron } \\
\text { macrocarpum }\end{array}$ & 1150 & 8.8 & 9.2 & 4.6 & 5.84 & 730 & 1.78 & 3.6 \\
\hline 22 & Cordia millenii & 840 & 11.2 & 8.2 & 3.2 & 3.05 & 520 & 1.70 & 2.4 \\
\hline 23 & Khaya ivorensis & 790 & 9.4 & 7.8 & 2.8 & 2.78 & 520 & 1.72 & 1.2 \\
\hline 24 & $\begin{array}{c}\text { Kaempferia } \\
\text { galanga }\end{array}$ & 820 & 3.6 & 4.0 & 6.2 & 2.12 & 670 & 1.74 & 7.2 \\
\hline
\end{tabular}

major active ingredients found in plant based medicines [22]; it serves as caustics for cationic dyes (tannin dyes) used in the dyestuff industry as well as in the production of inks (iron gallate ink). Other uses of tannin are for wine, fruit juice, and beer clarification in food industries [23] Tannins are used in the dyestuff industry as caustics for cationic dyes (tannin dyes), and also in the production of inks (iron gallate ink), textile dyes, antioxidants in beverages, and coagulant in rubber production [24] as well as possessing antiviral, antibacterial, and antitumor activity $[22,25,26]$. Tannin has been reported to selectively inhibit HIV replication [27].
Therefore, the above listed Nigerian softwoods have potential in the provision of tannin.

According to Braunwald et al. [28] cardiac glycoside has been used in treatment of congestive heart failure due to its direct action which increases the force of myocardial contraction. They also explained that in the vascular system cardiac glycoside acts directly on the smooth muscles. Their effects on neural tissues and indirect effect on electrical activities of the heart and vascular resistance as well as capacitance are equally reported [28]. Moringa oleifera, Afzelia bipindensis, Tetrapleura tetraptera, Combretodendron macrocarpum, and 
Cordia millenii in this study were shown to contain glycosides which could be exploited for their medicinal properties.

Flavonoids are known to have antioxidant effects and have been shown to inhibit the initiation, promotion, and progression of tumors [29]; reduction of coronary heart disease has been reported to be associated with intake of flavonoid [30]. This research has shown that Barteria nigritiana, Moringa oleifera, Combretodendron macrocarpum, Cordia millenii, Afrormosia laxiflora, and Sacoglottis gabonensis contain appreciable quantity of flavonoid. Apart from the antioxidant properties of flavonoid, other biological functions it possesses include protection against platelet aggregation, microorganisms, hepatotoxins, viruses, tumors, ulcers, free radicals, inflammation, and allergies [31].

Phenols are antioxidants in human and plants [32]. Some softwoods in this research such as Sacoglottis gabonensis, Pentaclethra macrophylla, Moringa oleifera, and Anogeissus leiocarpus may be exploited for their saponin content. Haslam [33] points to current interest in the potential for amelioration of diseases simply by improving the dietary intake of nutrients with antioxidant properties, such as vitamin $\mathrm{E}$, vitamin $\mathrm{C}, \beta$-carotene, and carotenoids, and plant phenolics such as tannins and flavonoids.

Plant lipids are important in paints production, pharmaceutical, and cosmetic raw materials as well as being sources for production of animal feeds. From the foregoing, extraction of lipids from nonfoliage parts of softwood (e.g., stems) is ideal for use as listed above. Thus stems of Anogeissus leiocarpus, Kaempferia galanga, Dichrostachys cinerea, and Allanblackia floribunda from the result of this research are ideal sources for lipid extraction.

Appreciable quantities of saponin are found in Anogeissus leiocarpus, Kaempferia galanga, Dichrostachys cinerea, and Allanblackia floribunda as shown in Tables 2 and 3 in this research. Saponins protects against microbial attack in plants; it is also useful in treating yeast and fungal infections [1].

According to Sodipo et al. [34] most phytochemicals serve as natural antibiotics, which assist the body in fighting microbial invasion and infections. Alkaloids, for instance, consist of chemical compounds that contain mostly basic nitrogen atoms which occur naturally, mainly, in plants but may be produced by bacteria, fungi, and animals. In this research, appreciable quantities of alkaloid were obtained in Cordia millenii, Sterculia oblonga, Amphimas pterocarpoides, and Khaya ivorensis (Table 3). Extraction of alkaloid from these softwoods could serve as a cheap and steady means of providing this secondary metabolite in industries where they are greatly needed. According to literature, alkaloids have a wide range of pharmacological activities including antimalarial (e.g., quinine), anticancer (e.g., homoharringtonine) [35], antibacterial (e.g., chelerythrine) [36], and antihyperglycemic activities (e.g., piperine) [37]. Alkaloids have equally been exploited for their importance in traditional pharmaceutical usage. Other alkaloids possess psychotropic (e.g., psilocin) and stimulant activities (e.g., cocaine, caffeine, and nicotine) and have been used as recreational drugs [37]. Although alkaloids carry out many metabolic activities in humans and other animals, they almost uniformly evoke a bitter taste [38].

\section{Conclusion}

Nigerian softwoods apart from their timber uses are also potential for traditional medicine. There have been well known usages of most of their foliage parts such as seeds and leaves in traditional medicine, but the stem has had less usage in the phytochemical application in industries and medicine. This research result has established through the investigation of their phytochemistry that they have potential in the industries particularly for pharmaceutical usages.

\section{Competing Interests}

The authors hereby declare that there are no competing interests in this work.

\section{Acknowledgments}

Researchers acknowledge the management of Godfrey Okoye University, Enugu, Nigeria, for provision of facilities which enhanced this research.

\section{References}

[1] N. Sheikh, Y. Kumar, A. K. Misra, and L. Pfoze, "Phytochemical screening to validate the ethnobotanical importance of root tubers of Dioscorea species of Meghalaya, North East India," Journal of Medicinal Plants Studies, vol. 1, no. 6, pp. 62-69, 2013.

[2] J. B. Harborne, Phytochemical Methods: A Guide to Modern Techniques of Plant Analysis, Chapman and Hall, London, UK, 1973.

[3] D. E. Okwu, "Phytochemicals and vitamin content of indigenous spices of South Eastern Nigeria," Journal of Sustainable Agriculture and the Environment, vol. 6, pp. 30-34, 2004.

[4] C. H. Manjula and K. Ammani, "Phytochemical analysis and pharmacological importance of Sophora interrupta leaves," International Journal of Research in Pharmaceutical and Biomedical Sciences, vol. 3, no. 4, pp. 1798-1804, 2012.

[5] O. I. Aruoma, "Free radicals, oxidative stress, and antioxidants in human health and disease," JAOCS, Journal of the American Oil Chemists' Society, vol. 75, no. 2, pp. 199-212, 1998.

[6] D. J. Lefer and D. N. Granger, "Oxidative stress and cardiac disease," The American Journal of Medicine, vol. 109, no. 4, pp. 315-323, 2000.

[7] M. A. Smith, C. A. Rottkamp, A. Nunomura, A. K. Raina, and G. Perry, “Oxidative stress in Alzheimer's disease," Biochimica et Biophysica Acta-Molecular Basis of Disease, vol. 1502, no. 1, pp. 139-144, 2000.

[8] S. Bhatia, R. Shukla, S. V. Madhu, J. K. Gambhir, and K. M. Prabhu, "Antioxidant status, lipid peroxidation and nitric oxide end products in patients of type 2 diabetes mellitus with nephropathy," Clinical Biochemistry, vol. 36, no. 7, pp. 557-562, 2003.

[9] P. Steer, J. Millgård, D. M. Sarabi et al., "Cardiac and vascular structure and function are related to lipid peroxidation and metabolism," Lipids, vol. 37, no. 3, pp. 231-236, 2002.

[10] R. W. J. Keay, C. F. A. Onochie, and D. P. Stanfield, Nigerian Trees, Department of Forest Research Publishers, Ibadan, Nigeria, 1964. 
[11] C. M. Ejikeme, C. S. Ezeonu, and A. N. Eboatu, "Determination of physical and phytochemical constituents of some tropical timbers indigenous to Niger Delta Area of Nigeria," European Scientific Journal, vol. 10, no. 18, pp. 247-270, 2014.

[12] A. Sofowara, Medicinal Plants and Traditional Medicine in Africa, Spectrum Books, Ibadan, Nigeria, 1993.

[13] H. Hikino, Y. Kiso, H. Wagner, and M. Fiebig, "Antihepatotoxic actions of flavonolignans from Silybum marianum fruits," Planta Medica, vol. 50, no. 3, pp. 248-250, 1984.

[14] B. A. Amadi, E. N. Agomuo, and C. O. Ibegbulem, Research Methods in Biochemistry, Supreme Publishers, Owerri, Nigeria, 2004.

[15] B. A. Boham and A. R. Kocipai, "Flavonoids and condensed Tannins from Leaves of Hawaiian Vaccinium vaticulatum and V. calycinium," Pacific Science, vol. 48, pp. 458-463, 1994.

[16] B. O. Obadoni and P. O. Ochuko, "Phytochemical studies and comparative efficacy of the crude extracts of some haemostatic plants in Edo and Delta States of Nigeria," Global Journal of Pure and Applied Sciences, vol. 8, no. 2, pp. 203-208, 2002.

[17] A. Munro and O. Bassir, “Oxalate in Nigerian vegetables," W.A Journal of Biological and Applied Chemistry, vol. 12, no. 1, pp. $4-8,1969$.

[18] AOAC, Official Methods of Analysis, Association of Official Analytical Chemists, Washington, DC, USA, 14th edition, 1984.

[19] E. E. Itoandon, S. O. A. Olatope, and O. O. Shobowale, "Preliminary phytochemical analysis and antimicrobial properties of crude extract of Combretodendron macrocarpum stem bark," Nigerian Food Journal, vol. 30, no. 2, pp. 51-56, 2012.

[20] C. Unuigbe, H. Okeri, O. Erharuyi, E. Oghenero, and D. Obamedo, "Phytochemical and antioxidant evaluation of Moringa oleifera (Moringaceae) leaf and seed," Journal of Pharmacy \& Bioresources, vol. 11, no. 2, pp. 51-57, 2015.

[21] I. M. Ahmad and A. M. Wudil, "Phytochemical screening and toxicological studies of aqueous stem bark extract of Anogeissus leiocarpus in rats," Asian Journal of Scientific Research, vol. 6, no. 4, pp. 781-788, 2013.

[22] E. Haslam, "Natural polyphenols (vegetable tannins) as drugs: possible modes of action," Journal of Natural Products, vol. 59, no. 2, pp. 205-215, 1996.

[23] G. Würdig and R. Woller, Chemie des Weines, Eugen Ulmer, Stuttgart, Germany, 1989.

[24] J. Falbe and M. Regitz, CD RÖMPP Chemie Lexikon, Version 1.0, Georg Thieme, Stuttgart, Germany, 1995.

[25] K. Khanbabaee and T. van Ree, "Tannins: classification and definition," Natural Product Reports, vol. 18, no. 6, pp. 641-649, 2001.

[26] N. Kakiuchi, M. Hattori, M. Nishizawa, T. Yamagishi, T. Okuda, and T. Namba, "Studies on dental caries prevention by traditional medicines. VIII. Inhibitory effect of various tannins on glucan synthesis by glucosyltransferase from Streptococcus mutans," Chemical and Pharmaceutical Bulletin, vol. 34, no. 2, pp. 720-725, 1986.

[27] Y. Kashiwada, L. Huang, R. E. Kilkuskie, A. J. Bodner, and K.-H. Lee, "New hexahydroxydiphenyl derivatives as potent inhibitors of HIV replication in H9 lymphocytes," Bioorganic and Medicinal Chemistry Letters, vol. 2, no. 3, pp. 235-238, 1992.

[28] E. Braunwald, R. D. Bloodwell, L. I. Goldberg, and A. G. Morrow, "Studies on digitals IV observations in man on the effects of digitalis preservations on the contractility of the nonfailing heart and on total vascular resistance," Journal of Clinical Investigation, vol. 40, no. 1, pp. 52-59, 1961.
[29] S. Y. Kim, J. H. Kim, S. K. Kim, M. J. Oh, and M. Y. Jung, "Antioxidant activities of selected oriental herb extracts," Journal of the American Oil Chemists' Society, vol. 71, no. 6, pp. 633-640, 1994.

[30] M. G. L. Hertog, E. J. M. Feskens, P. C. H. Hollman, J. B. Katan, and D. Kromhout, "Dietary antioxidant flavonoids and risk of coronary heart disease: the Zutphen Elderly Study," The Lancet, vol. 342, no. 8878, pp. 1007-1011, 1993.

[31] M. Z. Barakat, S. K. Shahab, N. Darwin, and E. I. Zahemy, "Determination of ascorbic acid from plants," Analytical Biochemistry, vol. 53, pp. 225-245, 1993.

[32] C. J. Dillard and J. B. German, "Phytochemicals: nutraceuticals and human health," Journal of the Science of Food and Agriculture, vol. 80, no. 12, pp. 1744-1756, 2000.

[33] E. Haslam, Practical Polyphenolics: From Structure to Molecular Recognition and Physiological Action, Cambridge University Press, Cambridge, UK, 1998.

[34] O. A. Sodipo, J. A. Akiniyi, and U. S. Ogunbano, "Studies on certain characteristics of extracts of bark of Pausinystalia johimbe and Pausinystalia macroceras (K.Schum.) Pierre ex Beille," Global Journal of Pure and Applied Sciences, vol. 6, no. 1, pp. 83-87, 2000.

[35] P. Kittakoop, C. Mahidol, and S. Ruchirawat, "Alkaloids as important scaffolds in therapeutic drugs for the treatments of cancer, tuberculosis, and smoking cessation," Current Topics in Medicinal Chemistry, vol. 14, no. 2, pp. 239-252, 2014.

[36] T. P. T. Cushnie, B. Cushnie, and A. J. Lamb, "Alkaloids: an overview of their antibacterial, antibiotic-enhancing and antivirulence activities," International Journal of Antimicrobial Agents, vol. 44, no. 5, pp. 377-386, 2014.

[37] S. Qiu, H. Sun, A. H. Zhang et al., "Natural alkaloids: basic aspects, biological roles, and future perspectives," Chinese Journal of Natural Medicines, vol. 12, no. 6, pp. 401-406, 2014.

[38] D. F. Rhoades, "Evolution of plant chemical defense against herbivores," in Their Interaction with Secondary Plant Metabolites, G. A. Rosenthal and D. H. Janzen, Eds., p. 41, Academic Press, New York, NY, USA, 1979. 

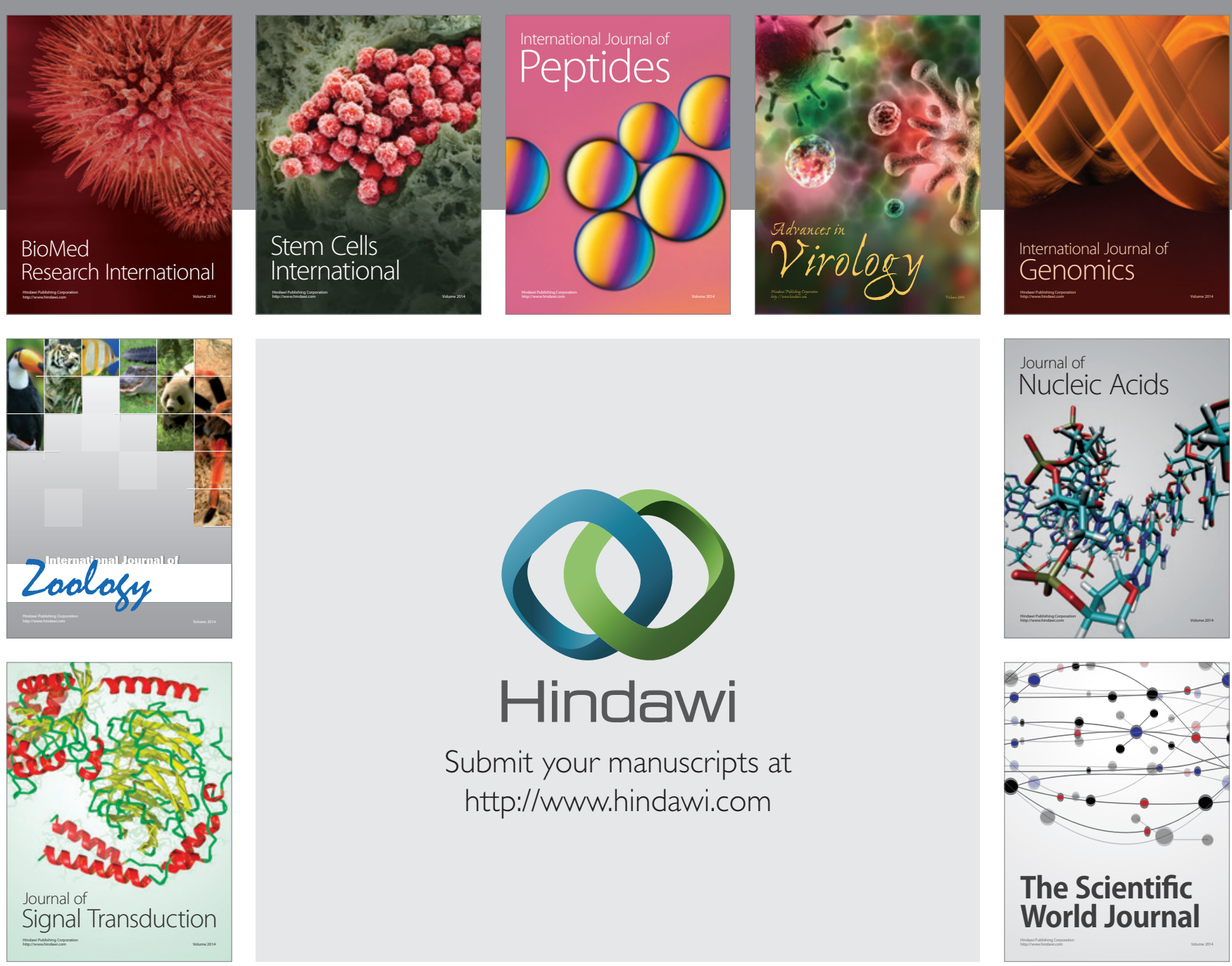

Submit your manuscripts at

http://www.hindawi.com
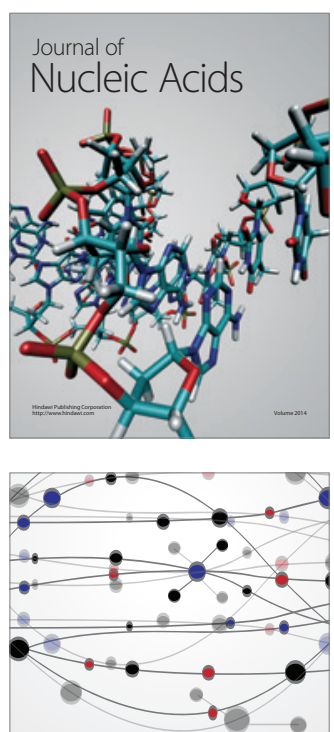

The Scientific World Journal
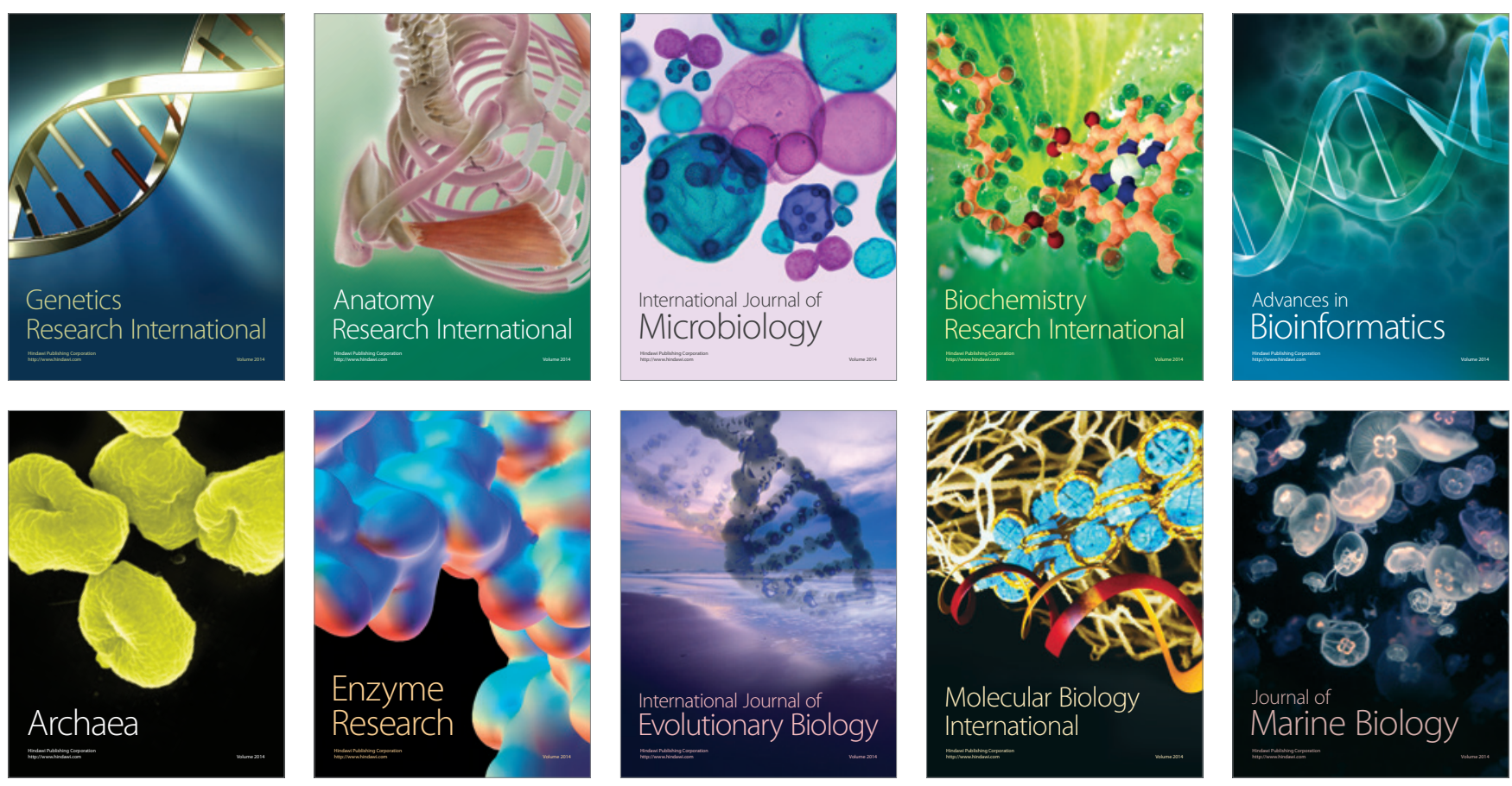